\title{
Blood Lipids in Treated Diabetics
}

\author{
A.D. Perrett, A.S. Rowe, M. Shahmanesh, S.P. Allison and M. Hartog \\ University Department of Medicine, Bristol Royal Infirmary, Bristol, England \\ Received: June 13, 1973, and in revised form: November 19, 1973
}

\begin{abstract}
Summary. Blood lipid estimations were performed on 118 diabetics receiving different forms of troatment and with varying degrees of control of their diabetes. Elevated blood lipids were found predominantly in elderly patients being treated with hypoglycaemic drugs and could not be accounted for by poor diabetic control. Patients with
\end{abstract}

elevated plasma triglycerides were significantly heavier than those with normal levels.

Key words: Diabetes Mellitus, blood lipid abnormalities, overweight, oral hypoglycaemic drugs, diabetic control.
Lipid abnormalities are common in untreated and uncontrolled diabetes $[1-5]$. There is good evidence that these abnormalities improve with the initial control of ketosis and hyperglycaemia $[2,5-10]$, but there is controversy as to whether or not this improvement in the blood lipids persists in patients receiving maintenance anti-diabetic therapy $[1,5,11-13]$. The object of the present study was to determine the incidence of blood lipid abnormalities in diabetics maintained on different forms of treatment and with varying degrees of control of their diabetes.

\section{Material and Methods}

One hundred and eighteen juvenile and maturity onset diabetic patients were studied and have been divided into groups on the basis of their diabetic control.

\section{Group 1 ("Good Control") 51 Subjects}

Each of these had at least two successive monthly fasting blood sugar levels of less than $150 \mathrm{mg} / 100 \mathrm{ml}$ and a mean of such values of less than $140 \mathrm{mg} / 100 \mathrm{ml}$. Their degree of glycosuria on repeated home testing was less than $0.25 \%$. In addition, single $24 \mathrm{~h}$ urine samples were collected on each subject (in $2 \mathrm{ml} 0.5 \%$ chlorhexidine as preservative), the sugar content of which was also less than $0.25 \%$. All blood and urine sugars were measured by a neocuprin autoanalyser method [14].

\section{Group 2 ("Fair Control") 46 Subjects}

Each of these had two or more successive monthly fasting blood sugars of less than $225 \mathrm{mg} / 100 \mathrm{ml}$ with a mean of less than $200 \mathrm{mg} / 100 \mathrm{ml}$. Urine sugars were less than $1.0 \%$ on repeated home testing and $24 \mathrm{~h}$ urine collections.

\section{Group 3 ("Poor Control") 21 Subjects}

The subjects in this group failed to satisfy the requirements of Group 2. None were ketotic at the time of study.

The characteristics of the three groups with regard to age, sex, treatment and duration of diabetes are shown in Table 1.

\section{Body Weight}

Body weight was expressed as the percentage of "ideal weight" which was taken as the midpoint of the range of ideal weight for subjects of medium frame, from the Metropolitan Life Insurance Company Tables [19].

\section{Blood Lipid Measurements}

Following a $12 \mathrm{~h}$ fast, venous blood was taken for measurement of serum cholesterol, plasma triglycerides and lipoprotein electrophoresis. Two or more samples at monthly intervals were obtained from 85 percent of patients. In the remainder a single specimen was examined.

The serum cholesterol was estimated by a modification of the Zlatkis method [15], and the normal level taken to be less than $280 \mathrm{mg} / 100 \mathrm{ml}$.

Plasma triglycerides were measured either by the standard Boehringer kit method [16], or by an autoanalyser method [17] and the normal level taken as less than $160 \mathrm{mg} / 100 \mathrm{ml}$. The results with the two methods agreed well. Thus 24 samples analysed by each method gave mean values of $100.7 \mathrm{mg} / 100 \mathrm{ml}$ (Boehringer kit) and $96.1 \mathrm{mg} / 100 \mathrm{ml}$ (auto analyser). A paired $t$ test on these results gave a value of $t=1.12$ showing no significant difference.

Lipoprotein electrophoresis was carried out on agarose gel according to the method of Noble [18].

\section{Results}

There was no clear difference in the mean serum cholesterol or plasma triglyceride levels between the 
three groups (Table 1). Plasma triglycerides from 3 subjects were exceptionally high and were excluded from this analysis for fear of undue weighting of the means. patients $(>50)$ the apparently higher incidence of triglyceride abnormalities in the tablet treated group, as compared with those on insulin, was of borderline significance $(p<0.1$.

Table 1. Details of patients studied with their blood lipids, and fasting blood sugar levels and body weights

\begin{tabular}{|c|c|c|c|c|c|c|c|c|c|c|c|c|c|}
\hline & \multirow[t]{2}{*}{ No. } & \multicolumn{2}{|l|}{ Age } & \multicolumn{2}{|c|}{ Sex } & \multirow{2}{*}{$\begin{array}{l}\text { Duration } \\
\text { diabetes } \\
\text { (yrs.) }\end{array}$} & \multicolumn{3}{|c|}{$\begin{array}{l}\text { Treatment } \\
\text { (No. patients) }\end{array}$} & \multirow{2}{*}{$\begin{array}{l}\text { FBS } \\
(\mathrm{mg} / 100 \mathrm{ml}) \\
\mathrm{m} \pm \mathrm{s} . \mathrm{d} .\end{array}$} & \multirow{2}{*}{$\begin{array}{l}\text { Serum } \\
\text { cholesterol } \\
(\mathrm{mg} / 100 \mathrm{ml}) \\
\mathrm{m} \pm \text { s.d. }\end{array}$} & \multirow{2}{*}{$\begin{array}{l}\text { Plasma tri- } \\
\text { glycerides } \\
(\mathrm{mg} / 100 \mathrm{ml}) \\
\mathrm{m} \pm \text { s.d. }\end{array}$} & \multirow{2}{*}{$\begin{array}{l}\text { Wt. } \\
\text { (\% ideal) } \\
\text { m I s.d. }\end{array}$} \\
\hline & & Mean & Range & $\mathrm{M}$ & $\mathbf{F}$ & & $\begin{array}{l}\text { In- } \\
\text { sulin }\end{array}$ & $\begin{array}{l}\text { Oral } \\
\text { drug }\end{array}$ & $\overline{\operatorname{diet}}$ & & & & \\
\hline Group 1 & & & & & & & & a & & & & d & \\
\hline $\begin{array}{l}\text { "Good } \\
\text { control" }\end{array}$ & 51 & 57 & $13-78$ & 32 & 19 & 4.0 & 7 & 38 & 6 & $109 \pm 18$ & $227 \pm 46$ & $121 \pm 49$ & $110 \pm 17$ \\
\hline $\begin{array}{l}\text { Group } 2 \\
\text { "Fair } \\
\text { control" }\end{array}$ & 46 & 49 & $11-69$ & 26 & 20 & 6.3 & 33 & $\begin{array}{l}\mathrm{b} \\
11 .\end{array}$ & 2 & $149 \pm 25$ & $229 \pm 45$ & e $117 \pm 49$ & $109 \pm 15$ \\
\hline Group 3 & & & & & & & & c & & & & & \\
\hline $\begin{array}{l}\text { "Poor } \\
\text { control" }\end{array}$ & 21 & 50 & $16-73$ & 12 & 9 & 10.0 & 20 & 1 & 2 & $245 \pm 58$ & $219 \pm 43$ & $109 \pm 43$ & $107 \pm 17$ \\
\hline Total & 118 & 53 & $11-78$ & 70 & 48 & 6.9 & 60 & 50 & 8 & & & & \\
\hline
\end{tabular}

a Sulphonylureas 24, Phenformin 12, Combined 2.

b Sulphonylureas 4, Phenformin 5, Combined 2.

c Sulphonylureas 1 .

d This figure excludes two patients with plasma triglyceride levels of 680 and $361 \mathrm{mg} / 100 \mathrm{ml}$.

e This figure excludes one patient with a plasma triglyceride level of $342 \mathrm{mg} / 100 \mathrm{ml}$.

Table 2. Incidence of abnormal blood lipids related to age and treatment

\begin{tabular}{|c|c|c|c|c|c|c|}
\hline & \multicolumn{3}{|c|}{$\begin{array}{l}\text { Insulin treated } \\
\text { (60 patients) }\end{array}$} & \multicolumn{3}{|c|}{$\begin{array}{l}\text { Oral hypoglycaemic drugs } \\
\text { (50 patients) }\end{array}$} \\
\hline & \multicolumn{2}{|l|}{$\overline{\text { Age }}$} & \multirow[t]{2}{*}{ Total } & \multicolumn{2}{|l|}{$\overline{\text { Age }}$} & \multirow{2}{*}{ Tota } \\
\hline & $\begin{array}{l}50 \\
(29 \text { patients })\end{array}$ & $\begin{array}{l}\$ 50 \\
(31 \text { patients) }\end{array}$ & & $\begin{array}{l}<50 \\
(5 \text { patients) }\end{array}$ & $\stackrel{\$ 50}{(45 \text { patients })}$ & \\
\hline $\begin{array}{l}\text { Raised serum } \\
\text { cholesterol } \\
\text { Raised plasma }\end{array}$ & 1 & 4 & 5 & 0 & 8 & 8 \\
\hline $\begin{array}{l}\text { triglycerides } \\
\text { Any abnor- } \\
\text { mality of } \\
\text { blood lipids }\end{array}$ & $\begin{array}{l}1 \\
2\end{array}$ & 4 & 5 & 0 & 17 & 17 \\
\hline
\end{tabular}

Table 3. Overall data on all patients other than those treated with diet alone related to plasma triglyceride levels

\begin{tabular}{|c|c|c|c|c|c|c|c|c|}
\hline & $\begin{array}{l}\text { Plasma } \\
\text { triglycerides } \\
\text { (mg/100 ml) } \\
\mathrm{m} \pm \text { S.D. }\end{array}$ & $\begin{array}{l}\text { Fasting } \\
\text { blood sugar } \\
\text { (mg/100 ml) } \\
\text { m } \pm \text { S.D. }\end{array}$ & $\begin{array}{l}\text { Serum } \\
\text { cholesterol } \\
(\mathrm{mg} / 100 \mathrm{ml}) \\
\mathrm{m} \pm \text { S.D. }\end{array}$ & $\begin{array}{l}\text { Wt. } \\
\text { (\% ideal) } \\
\mathbf{m} \pm \text { S.D. }\end{array}$ & $\begin{array}{l}\text { Age } \\
\text { (yrs.) } \\
\text { m } \pm \text { S.D. }\end{array}$ & $\begin{array}{l}\text { Duration } \\
\text { diabetes } \\
\text { (yrs.) } \\
\mathrm{m} \pm \text { S.D. }\end{array}$ & $\begin{array}{l}\text { Onset } \\
\text { diabetes } \\
\text { before } \\
\text { age } 40\end{array}$ & $\begin{array}{l}\text { Number } \\
\text { treated } \\
\text { with } \\
\text { oral } \\
\text { drugs }\end{array}$ \\
\hline $\begin{array}{l}\text { Raised plasma } \\
\text { Triglycerides } \\
(n=12)\end{array}$ & $222.6 \pm 69$ & $146.1 \pm 55.9$ & $247.9 \pm 60.3$ & $119.2 \pm 14.5$ & $59.3 \pm 6.6$ & $4.89 \pm 5.5$ & $9.1^{\mathrm{a}}$ & $77.3^{\mathrm{a}}$ \\
\hline $\begin{array}{l}\text { Normal plasma } \\
\text { Triglycerides } \\
(n=88)\end{array}$ & $100 \pm 26.8$ & $153 \pm 58.4$ & $219.7 \pm 42.2$ & $107.1 \pm 15$ & $50.8 \pm 15.8$ & $6.54 \pm 5.8$ & $34.1^{\mathrm{a}}$ & $38^{a}$ \\
\hline Significance & $p<0.001$ & NS & $p<0.02$ & $p<0.001$ & $p<0.02$ & NS & - & - \\
\hline
\end{tabular}

a $\%$ of total in the group.

The incidence of abnormal blood lipids in the group of patients related to their age and treatment is shown in Table 2. Patients on diet alone were excluded from further analysis as the numbers were small. In the older
Nineteen of the 23 patients with elevated plasma triglyceride levels were overweight $(>10 \%$ above ideal weight) and the group of patients with elevated plasma triglycerides was heavier than the other subjects 
$(p<0.001)$. The women studied were significantly heavier than the men (mean $18.9 \%$ above ideal weight in the women, $3.3 \%$ in the men, $p<0.001$ ), and 14 of the 48 women had raised plasma triglyceride levels $(29.2 \%)$ as compared with 9 of the 70 men (12.9\%).

The overall data on all the patients, other than those treated with diet alone, in relation to their plasma triglyceride levels, are shown in Table 3 . There was no difference in fasting blood sugar levels and in duration of diabetes in those who had raised plasma triglycerides as compared with those who did not. The increased weight of the former group is again shown, as is the finding that they tended also to be older and have higher serum cholesterol levels than the latter group.

\section{Reproducibility of Blood Lipid Results}

Analysis of 96 paired cholesterol samples from individual patients showed that the standard error of the differences $(\mathrm{S})^{1}$ was $21.1 \mathrm{mg} / 100 \mathrm{ml}$. Likewise, 87 paired triglyceride samples showed a standard error of the differences of $28.4 \mathrm{mg} / 100 \mathrm{ml}$. As regards the error of the methods, repeated estimations of the sample for serum cholesterol showed a coefficient of variation of $1.38 \%$ and for plasma triglycerides (autoanalyser method) of $4.34 \%$.

\section{Lipoprotein Electrophoresis}

The serum lipoprotein electrophoresis results showed abnormalities of the Type II and Type IV patterns of hyperlipoproteinaemia and agreed with the blood triglyceride and cholesterol estimations. No patient with hyperchylomicronaemia was seen.

\section{Discussion}

In this study of non ketotic diabetics, elevated plasma lipids were found predominantly in the older patients who were being treated with oral hypoglycaemic drugs. There was no obvious difference in diabetic control between those with and without abnormal blood lipids. The elevation of plasma triglycerides was more marked than that of the serum cholesterol. There are various possibilities that might account for these findings.

Thus the abnormal blood lipids might be attributable to the effect of the oral hypoglycaemic drugs. Such an explanation would be tempting in view of the recent report of a worsening of prognosis in diabetics treated with tolbutamide [20] and phenformin [21] and the association between raised plasma triglyceride levels and vascular disease $[11,22]$. This possibility, however, does not seem likely from other evidence that

$$
1 S=\sqrt{\frac{\Sigma \delta^{2}}{2 n}} \quad \begin{aligned}
& \delta=\text { difference in } \mathrm{mg} / 100 \mathrm{ml} \\
& n=\text { number of pairs }
\end{aligned}
$$

phenformin [23], tolbutamide and chlorpropamide [24] reduce serum triglyceride levels in diabetics.

It may be that the explanation of the higher plasma triglycerides in the oral hypoglycaemic drug treated group lies in a fundamental difference in the nature of maturity onset diabetes as compared with the juvenile onset type. It is also possible that some of our maturity onset diabetics with abnormal lipids were patients with an underlying primary hyperlipoproteinaemia, in whom associated diabetes is common [25]. Both these possibilities are clearly difficult to establish or refute.

An important feature of the present study is that, with few exceptions, those subjects who had elevated plasma triglyceride levels were also overweight and that, as a group, they were heavier than those with normal plasma triglycerides. This observation agrees with other recent studies of lipid abnormalities in diabetics [10, 26], although Lewis et al. [9] found no clear difference in triglyceride levels between lean and obese diabetics. A correlation between obesity and blood triglyceride levels has also been shown in non-diabetic subjects [27] and there is usually a fall of plasma triglycerides in both diabetics and non-diabetics with weight reduction [4]. Morris et al. [24], however, found that the plasma triglyceride levels fell in their diabetics with routine anti-diabetic treatment, despite a gain in weight. The incidence of hypertriglyceridaemia has been shown to be higher in diabetics found to be suffering from atherosclerosis [26]. In the present study we did not assess the incidence of atherosclerosis.

The most satisfactory dietary treatment of the non obese diabetic remains uncertain [4]. As regards the obese diabetic, however, the high incidence of elevated triglycerides which occurs, even in those who are apparently well controlled, provides yet another argument for maintaining caloric restriction until an ideal body weight has been achieved. In those patients whose serum lipids remain abnormal despite satisfactory weight loss, independent treatment of the hyperlipidaemia is indicated.

Acknowledgements. We are most grateiul to Drs. C.H. Bolton and G. Hunt for help with the blood lipid estimations and to Dr. C. A. Pennock for help with the statistics.

\section{References}

1. Schrade, W., Boehle, T.N., Bierman, E.L., Reader, G.I. : Fatty acid composition of lipid fractions in diabetic serum. Lancet 1963 I, 285-290

2. Sterky, G., Larsson, Y., Persson, B.: Blood lipids in diabetic and non-diabetic schoolchildren. Acta paediat. (Uppsala) 52, 11-21 (1963)

3. Fraser, R.: Metabolic disorders in diabetes. Brit. med. J. 1972 IV, $591-596$

4. Albrink, M.S., Davidson, P.C.: Dietary therapy and prophylaxis of vascular disease in diabetics. Med. Clin. N. Amer. 55, 877 - 887 (1971)

5. Hayes, T.M.: Plasma lipoproteins in adult diabetes. Clin. Endocr, 1, 247-251 (1972) 
6. Adlersberg, D., Eisler, L.: Circulating lipids in diabetes mellitus. J. Amer. med. Ass. 170, 1261-1265 (1959)

7. Schwartz, M.J., Mirsky, S., Schaefer, L.E.: The effect of phenformin hydrochloride on serum cholesterol and triglyceride levels of the stable adult. Metabolism 15, $808-822(1966)$

8. Chance, G.W., Albutt, E.C., Edkins, S.M.: Serum lipids and lipoproteins in untreated diabetic children. Lancet 1969 I, $1126-1128$

9. Lewis, B., Mancini, M., Mattock, M., Chait, A., Fraser, T.R.: Plasma triglyceride and fatty acid metabolism in diabetes mellitus. Europ. J. elin. Invest. 2, 445$453(1972)$

10. Nikkilä, E.A., Kekki, M.: Plasma triglyceride kinetics in diabetes mellitus. Metabolism, 22, 1-22 (1973)

11. Carlson, L.A., Bottiger, L.E.: Ischaemic heart disease in relation to fasting values of plasma triglycerides. Lancet 1972 I, $865-868$

12. Albrink, M.J., Lavietes, P.H., Man, E.G.: Vascular disease and serum lipids in diabetes mellitus. - $\mathrm{Ob}$ servations over 30 years. Ann. Int. Med. 58, 305-323 (1963)

13. New, M.I., Roberts, T.N., Bierman, E.L., Reader, G. G.: The significance of blood lipid alteration in diabetes mellitus. Diabetes 12, 208-212 (1963)

14. Moore, G.R., Barnes, I.C., Pennock, C.A.: An improved rapid automated method for the estimation of blood glucose. Clin. chim. Acta 41, 439-440 (1972)

15. Franey, R.J., Amador, E. : Serum cholesterol measurement based on ethanol extraction and ferric chloridesulfuric acid. Clin. chim. Acta 21, 255-263 (1968)

16. Eggstein, M. : Triglyceride estimation. Klin. Wschr. 44, 267-273 (1966)

17. Kessler, Lederer: Technic on method number 78. In: Automation in analytical chemistry, p. 341-344. New York: L.T. Skeggs (1965)

18. Noble, R.P.: Electrophoretic separation of plasma lipoproteins in agarose gel. J. Lipid Res. 9, 693-700 (1968)
19. Statistical Bulletin of the Metropolitan Life Insurance Company 40 (1959)

20. Meinert, C.L., Knatterud, G.L., Prout, T.E., Klimt, C.R.: University group diabetic programme. - A study of the effects of hypoglycemic agents on vascular complications in patients with adult-onset diabetes. Diabetes 19, $789-830(1970)$

21. Knatterud, G.L., Meinert, C.L., Klimt, C.R., Osborne, R.K., Martin, D.B.: Effects of hypoglycemic agents on vascular complications in patients with adult-onset diabetes IV. A preliminary report on phenformin results. $J$. Amer. med. Ass. 217, 777 - 784 (1971)

22. Albrink, M.J.: Diet, diabetes and serum lipids. Diabetes $13,425-429$ (1964)

23. Schwartz, M.J., Mirsky, S., Schaefer, L.E.: Phenformin, serum lipids and diabetes mellitus. Lancet $\mathbf{1 9 6 5}$ I, 959

24. Morris, J.H., West, D.A., Bolinger, R.E. : Effect of oral sulphonylurea on plasma triglycerides in diabetes. Diabetes 13, 87-89 (1964)

25. Bradley, R.F.: Joslin's diabetes mellitus, p. 431. (Eds. Marble, A., White, P., Bradley, R.F., Krall, L.P.). Philadelphia: Lea and Febiger 1971

26. Santen, R.J., Willis, P.W., Fajans, S.S.: Atherosclerosis in diabetes mellitus. Arch. Int. Med. 130, 833$843(1972)$

27. Albrink, M.J., Meigs, J.W., Granoff, M.A.: Weight gain and serum triglycerides in normal men. New Engl. J. Med. 266, 484-489 (1962)

Dr. M. Hartog

Hon. Consultant Physician

Dept. of Medicine

Bristol Royal Infirmary

Bristol, BS $28 \mathrm{HW}$

England 